\title{
The top performers in vocational training
}

\author{
Margrit Stamm ${ }^{a}$, Michael Niederhauser ${ }^{a, *}$, Jakob Kost $^{a}$ \\ ${ }^{a}$ University of Fribourg
}

\begin{abstract}
In the course of a Swiss longitudinal study on the training paths of particularly able adolescents in the Swiss vocational training system, it became apparent that the "talent pool" (adolescents with above-average talents) had been overtaken by the "comparison group" (those with average talents). This surprising fact constitutes the starting point of the current article. Based on the question of who the top performers are, the article seeks to identify their characteristics and derives a set of predictors with which success in vocational training can be predicted. On the whole, the results indicate that training success is only attributable to general talent characteristics to a very limited extent, and is rather much more strongly based on behavioural characteristics and company-based standards. However, both behavioural characteristics and company-based standards can be moulded and supported. The results form an empirically grounded foundation for the promotion of gifted trainees in companies providing vocational training.
\end{abstract}

Keywords: Performance excellence, giftedness, ability promotion

\section{Introduction}

It is an empirically documented fact that gifted learners exist not just in grammar schools, but also in vocational training. Respective indications of this have been provided by scientific research accompanying support programmes such as the pilot project "Promoting high-performing apprentices in a sustainable fashion" (cf. Stein et al., 2003) or the foundation "Promotion of gifted students in vocational education training" (cf. Bals, 1996; Fauser \& Schreiber, 1996; Fauser \& Egger, 2005). They demonstrate that vocationally gifted apprentices are relatively successful, highly motivated, and ambitious. We know little about how their performances develop in the course of the vocational training and to what extent they differ from averagely talented apprentices in this respect. According to contemporary research on giftedness and talent which emphasizes the importance of analyzing previously unstudied population in a longitudinal perspective to understand the dynamics of the development of excellence (Subotnik \& Arnold, 1994), a Swiss longitudinal study examined the performance development of talented apprentices in vocational training (Stamm, 2007; Stamm et al., 2009). Astonishingly, in the third survey at the end of training, it was

\footnotetext{
${ }^{*}$ Corresponding author: Departement Erziehungswissenschaften, Rue P.-A. de Faucigny 2, CH-1700 Fribourg, michael.niederhauser@unifr.ch
}

(c) 2010 Sense Publishers. All rights reserved. 
shown that a considerable proportion of gifted apprentices ("talent pool") had lost their head start, and in part had been overtaken by the averagely talented apprentices ("comparison group"). This finding led us to the following question: Who are the top performers in vocational training, and how can they be characterised? Our article answers this question on the basis of the data of the Swiss longitudinal study mentioned above by subsequently presenting a set of predictors with which success in vocational training can be predicted. On this basis, the article discusses several explanations which can explain the phenomenon. Finally, these reasons lead into the discussion of consequences from a vocational pedagogical perspective for companies and for training.

\section{The current state of research on the development of (vocational) excellence}

\subsection{Research on giftedness and expertise}

This article asks what distinguishes the top performers, who master vocational demands in an outstanding fashion, from others, and what enables them to become experts. Both research on expertise and research on giftedness are concerned with this question, albeit from different perspectives. The two strands of research share a common interest in outstanding performance, but research on expertise differs from research on giftedness through its prospection. While research on giftedness is predominantly interested in competence factors that do not have to be realised - and thus does not yet regard a gifted student as an expert -research on expertise necessarily binds itself to the consideration of people who have already achieved outstanding performances in a particular area. At the same time, in many investigations (Chi et al., 1988; Schneider 1992; Gruber \& Ziegler, 1996), but also in retrospective biographical analyses (Trost \& Sieglen, 1992), it has transpired that prior knowledge or non-cognitive variables such as motivation, a long, qualitatively demanding practising and learning phase ("deliberate practice", cf. Ericsson et al., 1993) is attributed with far greater importance for the development of excellence than the moderating effects of intelligence. Eraut (1994) for example emphasizes the relevance of professional knowledge for excellence in profession. According to Schneider's (1999) "threshold model", however, there must be at least a slightly above-average intelligence to enable the non-cognitive conditions to determine whether peak performances are achieved. This is an indication that although motivation and other personal variables play a large role in the development of excellence, it can nevertheless not be assumed that motivation explains virtually everything and cognitive abilities virtually nothing. Based on the threshold hypothesis, it must be assumed rather that cognitive abilities have to reach a required minimum to enable outstanding professional performances, and that only then can other factors, above all motivational variables, come into play. In connection with the conception of giftedness, Renzulli (1978) points out the importance of above-average but not necessarily superior general abilities for performance in general or specific areas. In this regard Sternberg 
(1995) talks of the necessity of being "bright but not brilliant" (p. 366).

What importance do the intelligence measures actually hold in relation to performance? Traditionally, in order to answer this question, recourse has been taken to the most famous investigation from research on giftedness, the longitudinal Terman study (Terman \& Oden, 1959). This study demonstrated that high cognitive ability is associated with school and vocational performance and good social competence, high willpower and perseverance. Thus, there is a fair amount of evidence speaking in favour of an association between intelligence and performance. However, there is also another way of reading this study: After all, for $15 \%$ of the participants, school success, and also later professional success, failed to materialise. Thus, limitations are to be advised here. From the perspective of research on expertise, too, the findings rather speak against assuming too narrow an association, as provided that long practising and learning phases precede outstanding performances, a relatively low correlation between performance and general cognitive abilities can be expected. This assumption is supported by studies on the professional success of young employees (Wigdor \& Garner, 1982; Baird, 1985; Snyderman \& Rothman, 1986), while various meta-analyses from organisational psychology continue to bestow intelligence tests with a high predictive validity in the prognosis of professional success (Ceci, 1996).

Schmidt and Hunter (1998) acknowledge, however, that the correlations between performance and general cognitive abilities for job success prognoses are becoming smaller, but still amount to between $r=0.3$ and $r=0.5$. Conversely, Hulin et al. (1992) were able to show that with increasing job experience, the average correlation between job success and general performance measures decreases.

\subsection{Hypotheses on the effect of vocational practice on performance excellence}

The central question is therefore what effect continuous practical vocational training has on the development of excellent performance. There are three possible hypotheses to answer this question: the convergence, the divergence, and the noninteraction hypothesis (cf. Schmidt et al., 1988; as a summary, Ziegler \& Perleth, 1997). They have in common the conviction that higher talents (in the sense of general cognitive abilities) are expressed in terms of better performances at the beginning of the professional career. However, they differ in terms of their notions as to whether and how increasing vocational training or professional practice contributes to reducing, enlarging or maintaining the initial differences in performance. The divergence hypothesis claims that there is an increase in performance differences with increasing job experience, while the convergence hypothesis assumes a levelling out of job success between persons with differing levels of talent, and the noninteraction hypothesis purports a head start of the more talented during vocational training, which remains constant. Few empirical findings are available to check these hypotheses. While the findings of Baird (1985), McDaniel (1986), Schmidt et al. (1988) or Hulin et al. (1990) speak more in favour of the noninteraction hypothesis, the re- 
search overview of Ziegler and Perleth (1997) additionally points to evidence for the convergence hypothesis. Barely any study, however, provides evidence for the divergence hypothesis. Also the longitudinal study of Stamm et al. (2009) provides empirical support initially for the convergence hypothesis: The data show that up to and including the second vocational training year, the talent pool significantly stood out in terms of performance, but from the third year onwards it was overtaken by the comparison group. Thus, there are clear indications that apprentices with aboveaverage talents are not automatically successful on the job, and also not with the expected constancy. As a tendency, they even embody a specific group of underachievers, defined as apprentices who achieve clearly worse performances than one would expect based on their cognitive abilities (Stamm, 2007).

As high intelligence therefore does not constitute the sole predictor to forecast performance excellence, in this article, the question of the profiles of the top performers are of interest. In concrete terms, in the following, two questions should be answered:

1. In which areas of characteristics do high performers differ from average performers?

2. With which predictors can performance excellence upon completing the vocational training be predicted?

To examine talent profiles, personal and environmental factors and their influence on excellence in this article the Munich model of giftedness of Ziegler and Perleth (1997) was chosen (cf. Figure 1). The model represents an attempt to explain the development of high professional performance and distinguishes between innate personal ability factors, including area-specific prior knowledge and personal factors and environmental factors, which are for their part responsible for translating talent into outstanding performances on the path towards becoming an expert.

\section{Experimental design}

\subsection{Selection procedure and sample}

The longitudinal study of Stamm et al. (2009), which forms the empirical basis of this article, was carried out between 2004 and 2008. The aim of this study was to analyze the development of vocational gifted adolescents.

In 2004, by means of a three-stage selection procedure which encompassed both the measurement of cognitive abilities through Horn's (1983) performance testing system (Leistungsprüfungssystem, L-P-S) as well as further variables such as areaspecific prior knowledge and accelerated educational paths, from a population of 2,706 apprentices from various professional fields, 190 persons (6.6\%) with L-P-S scores above the cut-off criterion of 194 points were identified as gifted and included in the talent pool (experimental group). This group was compared to a randomly 


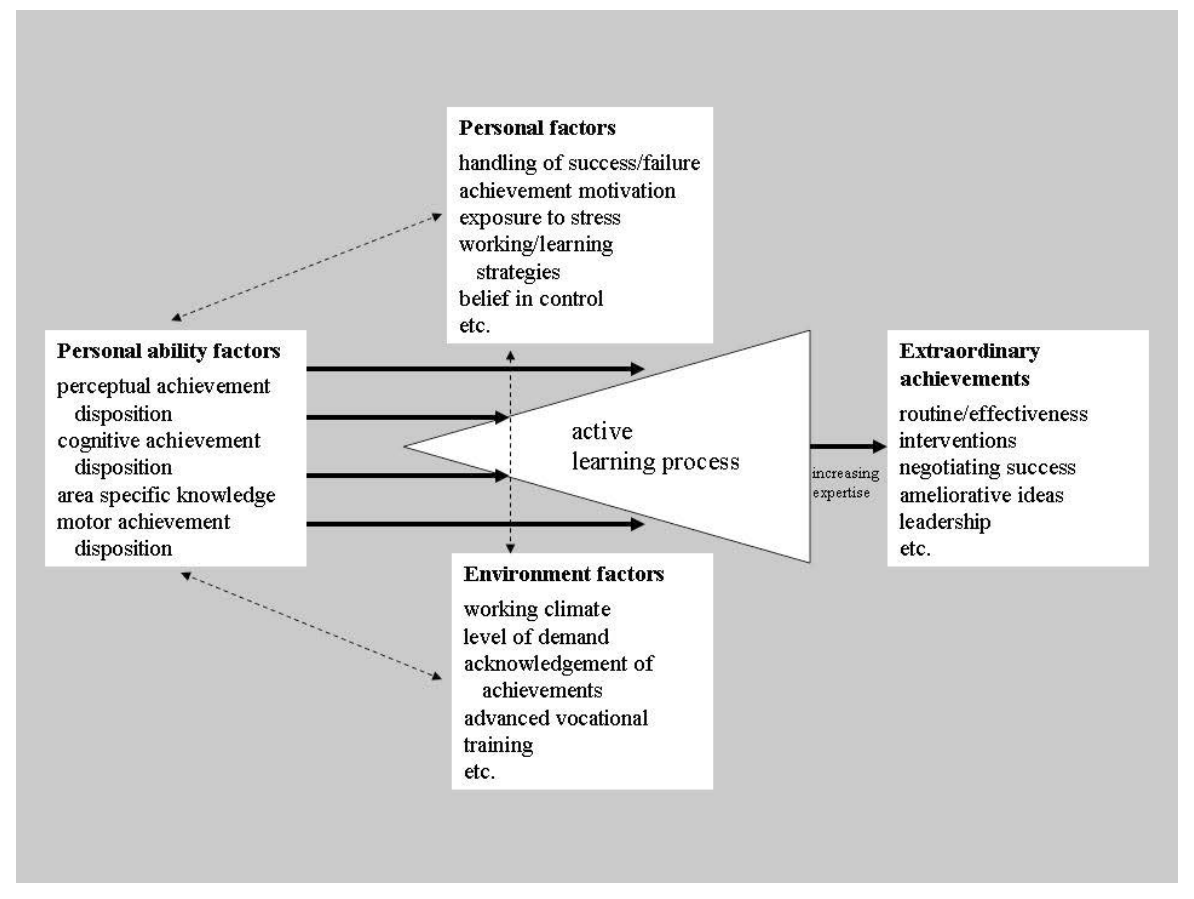

Figure 1: The Munich Dynamic Model of Talent \& Giftedness as a working model (Ziegler \& Perleth, 1997, p. 157)

selected comparison group of apprentices (189 persons) with average abilities. Both groups and their trainers were subsequently surveyed in four stages on a yearly basis through a written questionnaire on performance development.

\subsection{Instruments}

The instruments used to measure professional talent, the "Leistungsprüfungssystem" L-P-S of Horn (1983) and the T-dV2 of Skawran (1965), primarily measure the practical/technical intelligence, dexterity and spatial sense. The decisive factor for their choice was in addition to their relative cultural fairness that these instruments are, in contrast for example to KFT or the IST-70, two frequently used procedures in the diagnosis of giftedness, not geared exclusively to the collection of indicators of academic talent. Of the 14 subtests of the L-P-S the subtests 3 and 4 (general intelligence) were tested only shortened in the study in favour of the practical-intelligence and spatial sense (scales 7, 9, 10).

Furthermore for the characterisation of the high performers, the following instruments from the study of Stamm et al. (2009) are relevant: The area of non-cognitive characteristics was measured by the following instruments: Performance motiva- 
tion (following Heller, 2001; 3 items), stress coping scale (following Seiffge-Krenke 1989; 3 items), attributional style scale (following Stiensmeier-Pelster et al., 1994; 4 Items) and future perspectives (following Stein, 2004; 5 items). Sociodemographic data were measured through individual questions. The measurement of environmental characteristics took place through the work climate (following Eder, 1998; 4 items), the recognition of performance by the training companies and the vocational training school (following Wild, 2003; 3 items), the company support behaviour (in line with Wettstein, 2000 and Stein, 2004; 7 items), and leisure time activities and peer contacts (following Heller, 2001; 4 items) as well as family support (following Sauer \& Gamsjäger, 1996; Trudewind, 1975; 3 items). In total, the Cronbach's Alpha shows a satisfactory internal consistency for short scales (between $\alpha=0.61$ and $\alpha=0.89$ ), with the exception of the two scales recognition of performance and leisure time activities ( $\alpha=0.57$ and $\alpha=0.58$, respectively). Performance excellence was measured by an instrument according to Ripper and Weissschuh (1999) and following Schelten (2002) using external ratings of the trainees' performance by their trainers. The instrument records interdisciplinary, content-neutral but practically relevant key qualifications which are essential to complete the orders in the companies. The 12 items differentiate six areas of performance excellence: adhering to guidelines, social competence, innovation ability, communication ability, problemsolving, routine/effective action. The scale "total performance", which additively combines the six areas (transformed to value range 1-5) shows a good internal consistency at all measurement time points $(\alpha>0.82)$. In addition, vocational training school grades were recorded in the subjects of German and mathematics.

\subsection{Selection of high performers}

On the basis of the sample, which comprised a total of 379 persons (talent pool: $\mathrm{N}=190$; comparison group: $\mathrm{N}=189$ ), for the current analysis, trainees from a threeyear training programme are included, for whom performance data are available from all three measurement time points.

Using the following selection criteria, it is determined who should be assigned to the subpopulation of high performers (HP) and who should be assigned to the subpopulation of average performers (AP). The main criterion in this respect is the "total performance" at the third measurement time point in 2007 , i.e. the total value which the trainees had been given by their trainers based on their key competences in various areas.

High performers: "Total performance": $\geq 4.29$, i.e. at least one standard deviation above the mean value $\left(M_{t 3}=3.66 ; S D_{t 3}=0.63\right)$ of all trainees. $N=29$ (19\%).

These high performers originated from the most diverse of occupational fields, with the highest proportion lying in the area of "Organisation and administration" with $38 \%$ (11 persons), followed by the fields of "Information and communication", "Metal construction and mechanical engineering" and the technical professions with 
approx. $10 \%$. Of the 29 high performers, $69 \%$ are male and $31 \%$ are female.

Average performers: "Total performance": $\leq 3.98$, i.e. a maximum of half a standard deviation above the mean value $\left(M_{t 3}=3.66 ; S D_{t 3}=0.63\right)$ of all trainees. $N=101(66 \%)$. Like the high performers, the average performers came from the most diverse of fields, with the highest proportion lying at $50 \%$ for the area of "Organisation and administration", followed by "Metal construction and mechanical engineering" and the technical fields, with around 10\% each. Of the 101 average performers, $51 \%$ are male and $49 \%$ are female.

\section{Results}

The results are presented below in two steps. Following a differentiated analysis of the company-based performances, the relevant variables of the model are compared with the variable of excellent performance, defined as the dependent variable, and examined by means of univariate analyses of variance. Following this, a logistic regression analysis is calculated in order to determine which factors are mostly likely to be considered as predictors for performance excellence.

\subsection{Group differences}

First of all, the differences between the high performers and the average performers in the various areas of performance excellence according to the trainers' judgements are examined. Table 1 illustrates that the high performers clearly surpassed their average-performing colleagues upon completion of the training, with the differences between the two groups turning out to be highly significant in all areas of performance excellence. The greatest differences emerge in the areas of routine/effective action $\left(M_{H P}=4.63, M_{A P}=3.41, F=104.39, p<0.00\right)$ and adhering to guidelines $\left(M_{H P}=4.52, M_{A P}=3.45, F=89.83, p<0.00\right)$. The lowest, but nonetheless highly significant difference, is apparent in terms of social competence $\left(M_{H P}=4.72\right.$, $\left.M_{A P}=3.51, F=52.01, p<0.00\right)$. In between are the differences in the variables innovation ability $\left(M_{H P}=4.32, M_{A P}=3.08, F=78.18, p<0.00\right)$, communication ability $\left(M_{H P}=4.51, M_{A P}=3.37, F=77.76, p<0.00\right)$ and problem-solving $\left(M_{H P}=4.51, M_{A P}=3.14, F=73.86, p<0.00\right)$.

Similarly significant differences are shown in the progression on competence across the whole of the training. As can be seen in Figure 2, in comparison to the average performers, the high performers in the third year of training had also on the whole shown significantly better company-based performances in the first training year (t1: $M_{H P}=3.88, S D_{H P}=0.67 ; M_{A P}=3.43, S D_{A P}=0.64 ; F=7.92$, $p=0.01)$ and the second training year (t2: $M_{H P}=4.13, S D_{H P}=0.49 ; M_{A P}=3.35$, $\left.S D_{A P}=0.59 ; F=31.38, p=0.00\right)$. An analysis of variance with repeated measures shows that in addition to the highly significant between-subject effect of belonging to the high performers $(F(1,90)=59.59, p<0.01)$, there is also a highly significant interaction between group and measurement time point $(F(2,180)=15.76, p<0.01)$. 
Table 1: Group differences in the areas of "performance excellence" (external ratings by trainers, 2007)

\begin{tabular}{|c|c|c|c|c|c|c|c|}
\hline \multirow[t]{2}{*}{ Performance areas } & \multicolumn{2}{|c|}{$\mathrm{HP}(N=29)$} & \multicolumn{2}{|c|}{$\operatorname{AP}(N=101)$} & \multirow[t]{2}{*}{$F$} & \multirow[t]{2}{*}{$P$} & \multirow[t]{2}{*}{$\mathrm{Eta}^{2}$} \\
\hline & $\mathrm{M}$ & SD & $\mathrm{M}$ & SD & & & \\
\hline Adhering to guidelines & 4.52 & 0.41 & 3.45 & 0.56 & 89.83 & 0.00 & 0.41 \\
\hline Social competence & 4.72 & 0.45 & 3.51 & 0.86 & 52.01 & 0.00 & 0.29 \\
\hline Innovation ability & 4.32 & 0.50 & 3.08 & 0.70 & 78.18 & 0.00 & 0.38 \\
\hline Communication ability & 4.51 & 0.36 & 3.37 & 0.67 & 77.76 & 0.00 & 0.38 \\
\hline Problem-solving & 4.51 & 0.50 & 3.14 & 0.81 & 73.86 & 0.00 & 0.36 \\
\hline Routine/effective action & 4.63 & 0.36 & 3.41 & 0.60 & 104.39 & 0.00 & 0.45 \\
\hline Total performance ${ }^{a}$ & 4.54 & 0.19 & 3.33 & 0.43 & 211.45 & 0.00 & 0.62 \\
\hline
\end{tabular}

Note: $\mathrm{HP}=$ High performers $\mathrm{AP}=$ Average performers; Mean values $\mathrm{M}$ and standard deviations SD; univariate F; df: 1, 129; scale values: $1-5 ;{ }^{a}$ additive scale with value range $1-5$; higher values indicate more marked extents of the variables.

In order to examine whether the rise of the high performers, under consideration of the fact that this can be attributed in part to an "effect of regression to the mean", can be interpreted as an increase in performance, the covariance-based Mee-Chua test following Ostermann et al. (2008) was carried out with the performance data of the second and third measurement time point. The effect of regression to the mean has been repeatedly attributed in the literature to a lack of reliability of the measurement instruments (cf. Bortz \& Döring, 1995, p. 517) and according to Trautner (1992) it is particularly pronounced in extreme groups. If the "extreme group" of trainees is considered, who are distinguished by their highest performance values right at the top of the scale at the end of the training, then due to measurement errors, there is a high likelihood that this group on average lies closer to the average of all trainees in the previous measurement. The test shows that the p-value of the change effect only lies above the significance level of 0.05 from a hypothetical "true mean" smaller than 3.40 onwards. In view of the fact that the starting value of the high performers in the first survey round lies clearly above this value, $\left(M_{H L P}=3.88, S D_{H P}=0.67\right)$, an actual increase in performance in the second half of the training can be assumed, i.e. the change cannot solely be interpreted as a regression effect.

In order to be able to investigate the profile of the high performers, a one-factor analysis of variance was carried out. Table 2 shows that on the whole, only a small number of group differences could be determined. With regard to the socioeconomic characteristics, only one difference in terms of gender is found: Male learners are more numerous in the group of high performers than female learners $\left(M_{H P}=0.31\right.$, $\left.M_{A P}=0.49, \chi^{2}=3.09, p=0.08\right)$. No significant differences are found, either in terms of professional talent or in terms of the personality characteristics studied. High performers even show slightly lower values for the professional talent measured at the beginning of training than average performers $\left(M_{H P}=194.41, M_{A P}=195.60\right.$, $F=0.09, p=n . s$.$) . As a tendency, the high performers prove to be somewhat$ 


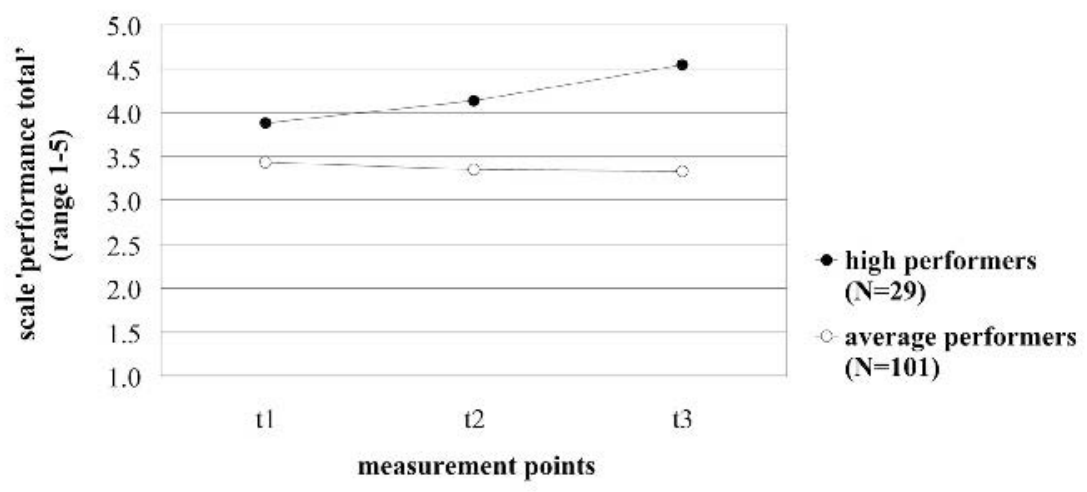

Figure 2: Company-based performance development (external assessment) of high performers and average performers

more motivated $\left(M_{H P}=4.66, M_{A P}=4.56, F=0.52, p=n . s.\right)$, less burdened by stress $\left(M_{H P}=2.62, M_{A P}=2.86, F=1.41, p=n . s.\right)$, more successful in dealing with failures at work $\left(M_{H P}=2.00, M_{A P}=2.43, F=3.69, p=n . s.\right)$, and less stressed when performing works in the company $\left(M_{H P}=2.03, M_{A P}=2.41\right.$, $F=3.14, p=n . s$.$) . The clearest group differences emerge in the assessment of$ one's professional future. High performers express significantly less pronounced anxieties about not finding a job $\left(M_{H P}=0.03, M_{A P}=0.26, \chi^{2}=6.91, p<0.00\right)$ or not managing to complete the vocational training $\left(M_{H P}=0.10, M_{A P}=0.29\right.$, $\left.\chi^{2}=4.03, p<0.05\right)$. They also tend to be less afraid of losing their enjoyment of work $\left(M_{H P}=0.28, M_{A P}=0.47, \chi^{2}=0.21, p=n . s\right.$. $)$ and are more likely to want to attend a university of applied science in the future $\left(M_{H P}=0.69, M_{A P}=0.49\right.$, $\chi^{2}=3.19, p=$ n.s.).

Also of interest are the differences in the characteristics of the training companies. As can be seen in Table 3, the high performers and the average performers only differ significantly in three characteristics. High performers work with clearly greater frequency in companies which acknowledge their performance $\left(M_{H P}=3.86\right.$, $\left.M_{A P}=3.29, F=5.03, p=0.03\right)$ and their trainers appreciate the importance of company support significantly more highly than those of the average performers $\left(M_{H P}=4.90, M_{A P}=4.57, F=9.17, p<0.00\right)$. Moreover, the deployment of the learners in special support groups in the companies of the high performers appears to be significantly more widespread than in the companies of the average performers $\left(M_{H P}=0.10, M_{A P}=0.02, \chi^{2}=4.14, p<0.05\right)$. In all other areas, the high and average performers do not differ. Accordingly, with regard to the characteristics of the training company, neither its size $\left(M_{H P}=4.86, M_{A P}=4.78, F=0.51, p=n . s\right.$. $)$ nor the general work climate $\left(M_{H P}=4.28, M_{A P}=4.11, F=0.76, p=n . s\right.$. $)$, nor the level of demand $\left(M_{H P}=3.93, M_{A P}=3.91, F=0.01, p=n . s\right.$. $)$ play a decisive role. 
Table 2: Group differences: Socioeconomic characteristics and school leaving qualification, professional talent, personality characteristics and future perspectives

\begin{tabular}{|c|c|c|c|c|c|c|c|}
\hline \multirow{2}{*}{$\begin{array}{l}\text { Independent } \\
\text { variables }\end{array}$} & \multicolumn{2}{|c|}{$\mathrm{HP}(N=29)$} & \multicolumn{2}{|c|}{$\mathrm{AP}(N=101)$} & \multirow[t]{2}{*}{$F$} & \multirow[t]{2}{*}{$P$} & \multirow[t]{2}{*}{$\mathrm{Eta}^{2}$} \\
\hline & $\mathrm{M}$ & SD & $\mathrm{M}$ & SD & & & \\
\hline \multicolumn{8}{|c|}{ Socioeconomic characteristics and school leaving qualification } \\
\hline Parents' education ${ }^{b}$ & 4.20 & 1.00 & 3.86 & 1.01 & 2.36 & n.s. & 0.02 \\
\hline Age 2007 & 19.11 & 0.73 & 19.23 & 0.87 & 0.32 & n.s. & \\
\hline $\begin{array}{l}\text { Sex }(0=\text { male; } \\
1=\text { female })\end{array}$ & 0.31 & 0.47 & 0.49 & 0.50 & $\chi^{2}=3.09$ & $(p=0.08)$ & \\
\hline Family size & 2.28 & 0.75 & 2.39 & 0.63 & 0.63 & n.s. & \\
\hline $\begin{array}{l}\text { Nationality } \\
(0=\text { Swiss; } 1=\text { Other })\end{array}$ & 0.04 & 0.19 & 0.13 & 0.34 & $\chi^{2}=2.00$ & n.s. & \\
\hline $\begin{array}{l}\text { School leaving qua- } \\
\text { lification (level } \\
\text { of demand })^{c}\end{array}$ & 2.79 & 0.05 & 2.66 & 0.66 & 0.92 & n.s. & \\
\hline \multicolumn{8}{|l|}{ Professional talent } \\
\hline L-P-S score $(1-221)$ & 194.41 & 21.11 & 195.60 & 17.78 & 0.09 & n.s. & \\
\hline \multicolumn{8}{|c|}{ Personality characteristics } \\
\hline $\begin{array}{l}\text { Performance motiva- } \\
\text { tion }^{c}\end{array}$ & 4.66 & 0.55 & 4.56 & 0.65 & 0.52 & n.s. & \\
\hline $\begin{array}{l}\text { Stress frequency } \\
\text { training company }{ }^{c}\end{array}$ & 2.62 & 1.01 & 2.86 & 0.95 & 1.41 & n.s. & \\
\hline $\begin{array}{l}\text { Stress burden } \\
\text { training company }{ }^{c}\end{array}$ & 2.03 & 1.12 & 2.41 & 0.98 & 3.15 & $(0.08)$ & \\
\hline $\begin{array}{l}\text { Ease of working } \\
\text { under time pres- } \\
\text { sure }^{c}\end{array}$ & 3.69 & 0.66 & 3.64 & 0.79 & 0.11 & n.s. & \\
\hline $\begin{array}{l}\text { Not becoming un- } \\
\text { nerved }^{c}\end{array}$ & 3.97 & 0.68 & 3.79 & 0.78 & 1.16 & n.s. & \\
\hline $\begin{array}{l}\text { Overcoming dif- } \\
\text { ficulties }^{c}\end{array}$ & 3.62 & 0.86 & 3.48 & 0.93 & 0.53 & n.s. & \\
\hline $\begin{array}{l}\text { Dealing poorly } \\
\text { with faiures } \\
\text { at work }\end{array}$ & 2.00 & 0.89 & 2.43 & 1.11 & 3.69 & $(0.06)$ & 0.03 \\
\hline $\begin{array}{l}\text { Enjoyment of } \\
\text { work }^{c}\end{array}$ & 4.00 & 0.76 & 3.83 & 0.90 & 0.82 & n.s. & \\
\hline Future perspectives & & & & & & & \\
\hline $\begin{array}{l}\text { Anxieties: Not } \\
\text { managing to com } \\
\text { plete training }{ }^{a}\end{array}$ & 0.10 & 0.31 & 0.29 & 0.45 & $\chi^{2}=4.03$ & $p<0.05$ & \\
\hline $\begin{array}{l}\text { Anxieties: Not } \\
\text { finding a job }\end{array}$ & 0.03 & 0.19 & 0.26 & 0.44 & $\chi^{2}=6.91$ & $p<0.00$ & \\
\hline $\begin{array}{l}\text { Anxieties: Not } \\
\text { enjoying work }\end{array}$ & 0.28 & 0.45 & 0.47 & 0.47 & $\chi^{2}=0.21$ & n.s. & \\
\hline $\begin{array}{l}\text { Attending uni- } \\
\text { versity of ap- } \\
\text { plied sciences }\end{array}$ & 0.69 & 0.47 & 0.49 & 0.50 & $\chi^{2}=3.19$ & $(p=0.07)$ & \\
\hline $\begin{array}{l}\text { Change in occu- } \\
\text { pational field }\end{array}$ & 0.44 & 0.51 & 0.41 & 0.49 & $\chi^{2}=0.09$ & n.s. & \\
\hline
\end{tabular}

Note: HP=High Performers, AP=Average Performers; Mean values M and standard deviations SD; univariate F; case numbers can vary due to missing values; ${ }^{a}$ two-point scale $\left(0=\right.$ no, $1=$ yes), ${ }^{b}$ three-point scale $(1-3)$; ${ }^{c}$ five-point scales (1-5), higher values indicate more marked extents of the variables. 
Table 3: Group differences: Characteristics of the training company and professional support

\begin{tabular}{|c|c|c|c|c|c|c|c|}
\hline \multirow{2}{*}{$\begin{array}{l}\text { Independent } \\
\text { variables }\end{array}$} & \multicolumn{2}{|c|}{$\mathrm{HP}(N=29)$} & \multicolumn{2}{|c|}{$\operatorname{AP}(N=101)$} & \multirow[t]{2}{*}{$F$} & \multirow[t]{2}{*}{$P$} & \multirow[t]{2}{*}{$\mathrm{Eta}^{2}$} \\
\hline & M & SD & $\mathrm{M}$ & SD & & & \\
\hline \multicolumn{8}{|c|}{ Characteristics of training company } \\
\hline Size of company ${ }^{a}$ & 4.86 & 0.36 & 4.79 & 0.43 & 0.51 & n.s. & \\
\hline $\begin{array}{l}\text { Work climate/envi } \\
\text { ronment }\end{array}$ & 4.28 & 0.88 & 4.11 & 0.92 & 0.76 & n.s. & \\
\hline $\begin{array}{l}\text { Hectic pace of com- } \\
\text { pany }\end{array}$ & 2.48 & 0.74 & 2.40 & 0.86 & 0.21 & n.s. & \\
\hline $\begin{array}{l}\text { Importance of well- } \\
\text { being }\end{array}$ & 4.50 & 0.69 & 4.37 & 0.61 & 0.99 & n.s. & 0.01 \\
\hline $\begin{array}{l}\text { Level of demand of } \\
\text { training company }\end{array}$ & 3.93 & 0.75 & 3.91 & 0.77 & 0.01 & n.s. & \\
\hline $\begin{array}{l}\text { Recognition of per- } \\
\text { formance }\end{array}$ & 3.86 & 0.99 & 3.29 & 1.26 & 5.03 & 0.03 & 0.04 \\
\hline \multicolumn{8}{|l|}{ Professional support } \\
\hline $\begin{array}{l}\text { Vocational "matura" } \\
\text { (A-level equivalent) } \\
\text { class }(0=\text { no, } 1=\text { yes })\end{array}$ & 0.28 & 0.45 & 0.27 & 0.45 & $\chi^{2}=0.00$ & n.s. & \\
\hline $\begin{array}{l}\text { Importance of pro- } \\
\text { fessional support }^{a}\end{array}$ & 4.90 & 0.31 & 4.57 & 0.56 & 9.17 & 0.00 & 0.07 \\
\hline \multicolumn{8}{|c|}{ Support techniques $(0=\text { no, } 1=\text { yes })^{a}$} \\
\hline Adaptation of tasks & 0.75 & 0.44 & 0.75 & 0.43 & $\chi^{2}=0.00$ & n.s. & \\
\hline Enrichment & 0.45 & 0.51 & 0.41 & 0.49 & $\chi^{2}=0.14$ & n.s. & \\
\hline Acceleration & 0.34 & 0.48 & 0.23 & 0.42 & $\chi^{2}=1.48$ & n.s. & \\
\hline Support group & 0.10 & 0.31 & 0.02 & 0.14 & $\chi^{2}=4.14$ & $p<0.05$ & \\
\hline
\end{tabular}

$\mathrm{HP}=$ High performers, $\mathrm{AP}=$ Average performers; Mean values $\mathrm{M}$ and standard deviations $\mathrm{SD}$; univariate $\mathrm{F}$; case numbers can vary due to lack of values; five-point scales (1-5), higher values indicate more marked extent of variables; ${ }^{a}$ Information provided by trainers.

\subsection{Associations between giftedness characteristics and performance excellence}

In a final evaluation step, the aim is to determine, using a logistic regression model, the predictors with which performance in vocational training can be forecast. The selection of the predictors was oriented towards our working model, including the insights from the bivariate analyses. The conceptual and perceptual abilities, operationalised through the L-P-S, are also included in the list of predictors in order to compare the factors determined with the traditionally most fundamental personality characteristic of research on giftedness and to conduct a multivariate analysis thereof. The results of the logistic regression analysis can be seen in Table 4. The quality of the general model with the selected predictors is acceptable, at $R^{2}=0.39$ 
(following Nagelkerke, 1991).

Table 4: Logistic regression on prediction of high performers $(0=$ average performers, $1=$ high performers)

\begin{tabular}{|c|c|c|c|c|}
\hline Predictors & $\beta$ & S.E & Wald & Sig. \\
\hline \multicolumn{5}{|c|}{ Sociodemographic characteristics and school biography } \\
\hline Parents' education & 0.20 & 0.31 & 0.39 & 0.53 \\
\hline $\operatorname{Sex}(0=$ male; $1=$ female $)$ & $-1.78^{*}$ & 0.74 & 5.72 & 0.02 \\
\hline Nationality $(0=$ Swiss, $1=$ Other $)$ & -1.12 & 1.33 & 0.71 & 0.40 \\
\hline $\begin{array}{l}\text { Enjoyed compulsory school period } \\
\text { Professional talent }\end{array}$ & -0.13 & 0.48 & 0.07 & 0.79 \\
\hline $\begin{array}{l}\text { L-P-S score } \\
\text { Personality characteristics }\end{array}$ & 0.01 & 0.02 & 0.59 & 0.44 \\
\hline Performance motivation & 0.81 & 0.60 & 1.85 & 0.17 \\
\hline Stress burden training company & -0.35 & 0.35 & 0.98 & 0.32 \\
\hline $\begin{array}{l}\text { Dealing poorly with work failures } \\
\text { Characteristics of training company }\end{array}$ & -0.37 & 0.35 & 1.16 & 0.28 \\
\hline Work climate/environment & 0.20 & 0.48 & 0.18 & 0.67 \\
\hline $\begin{array}{l}\text { Recognition of performance } \\
\text { Professional support }\end{array}$ & $0.77^{*}$ & 0.38 & 4.04 & 0.04 \\
\hline Importance of company support for trainers & $2.76^{*}$ & 1.24 & 4.98 & 0.03 \\
\hline Support group & $3.56^{*}$ & 1.84 & 3.76 & 0.05 \\
\hline Constants & -22.04 & 8.53 & 6.67 & 0.01 \\
\hline
\end{tabular}

Notes: $N=114 ;-2 \log$ likelihood $=84.16 ;$ Cox \& Snell $R^{2}=0.25 ;$ Nagelkerke $R^{2}=.39$; ${ }^{*} p<0.05,{ }^{* *} p<0.01$

In terms of the socioeconomic characteristics and the school biography, a significant negative effect is only found for gender $(\beta=-1.78$, Wald $=5.72, p<0.05)$. This can be attributed to the fact that in the group of high performers, male learners are more frequently represented than female learners. With regard to professional talent, the L-P-S test value does not show any effect $(\beta=0.01$, Wald $=0.59, p>0.05)$. Hence, higher cognitive abilities are also not associated with better company-based performances at the end of the training in the multivariate analysis. With regard to the predictors in the area of personality characteristics, although the effects of performance motivation and stress burden in the company are in line with expectations in terms of their direction, they are nevertheless not significant. Learners with high motivation and a stress burden that is perceived to be low tend to be more likely to be among the high performers. The predictors in the area of the characteristics of the training company point to a positive, albeit not significant, effect of work climate and a significant effect for the recognition in the training company $(\beta=0.77$, $W$ ald $=4.04, p<0.05)$. The more that outstanding performances in the training company are acknowledged, the more likely learners will achieve excellent performances at the end of the training. In the area of professional support, the significant 
positive effect $(\beta=2.76$, Wald $=4.98, p<0.05)$ means that a high awareness of support of the trainers increases the likelihood that their trainees will be among the high performers at the end of their vocational training. Finally, the just significant positive effect for professional support in special support groups $(\beta=3.56$, Wald $=3.76, p<0.05)$ signifies that trainees who are supported in this way are more likely to achieve excellent performances at the end of their training.

If one reviews the predictors as a whole, then three predictive factors prove to be the most important: the recognition in the training company, the awareness of support of the trainers, as well as the support in special support groups. The factors of performance motivation and ability of learners to deal with failures at work only have moderate to weak predictive quality. All other factors show in general only a very weak or even no predictive effect at all.

\section{Discussion}

This article focused on the two questions of (1) the characteristics of the top performers in vocational training and (2) the predictors with which excellent performance in vocational training can be forecast. These will be discussed in summary below.

With regard to the first question, a clear profile of high performers is shown, which is distinct from that of average performers. The high performers tended to be more motivated, more resilient, less susceptible to stress, and showed significantly less pronounced anxieties regarding their professional future than learners with average performances. In this respect, the influence of cognitive abilities proved to be relatively unimportant, and as a tendency even pointed in the opposite direction. At the end of the training, the top performers were no longer characterised as those with the highest potential for giftedness, but rather as those who were highly motivated and had received favourable support. The learners who were particularly successful at the end of the training already stood out significantly from the rest at the beginning of the training, and improved continuously, while the performances of the other trainees remained at a constant level. The results of the analyses conducted imply that the clear rise of the top performers in the second half of their training is not solely attributable to an "effect of regression to the mean" and can accordingly be interpreted as an increase in performance. It should be taken into account that our investigation is unable to examine the role of job-field-specific influences from design-specific perspectives. Due to sample size the question couldn't be examined for example, if there exist systematic differences between the professional fields concerning the analysed constructs like vocational talent and areas of performance excellence. Another aspect with connection to job-field-specificity is to what extent an instrument which records key qualifications is a valid indicator for excellent performance in a specific area of vocational training.

The second question can be answered such that the recognition of good performances in the training company, the awareness of support on the part of the trainers, and the support in special support groups prove to be the best predictors. In particu- 
lar, the support in special support groups points to the presence of a certain awareness of support of the trainers, as this form generally constitutes a very "consciously" applied form of support. Correspondingly, the development of excellent performance also demands a high degree of consciousness on the part of the trainers, together with a conscious and targeted deployment of support techniques.

Finally, we assess the relevance of the results of this study and ask which questions should be taken into account in future studies.

- First of all, the profiles of the high performers impressively demonstrate that above-average performances do not necessarily presuppose above-average talents. Cognitive abilities are a necessary, but not sufficient, prerequisite when the concern is with explaining the training success of vocational learners. The latter is substantially more strongly dependent on other determinants. One becomes a top performer if one possesses both the suitable personal characteristics such as motivation and stress resistance, and also has the benefit of specific company support and stimulation.

- On this basis, at least a part of the talent pool has to be described as underachievers, as they possess a high potential but do not realise it to the expected degree. Thus, the empirically determined low association between performance and cognitive abilities can also be taken as an indication for a type of "coalition of mediocrity".

- Consequently, this also addresses possibly the most relevant question of our study: Although this question can only be answered interpretatively based on our findings, the three interpretation attempts formulated here form a suitable basis for further studies.

- As performance convergence arises in the case of repetitive activities, but the variance, however, increases with increasing action complexity, it can be assumed for a start that the members of the talent pool had to work to a stronger extent in training settings that primarily served purposes of repetition. However, we know that, particularly in persons with above-average talents, such activities have a counterproductive effect on performance development.

- This could apply similarly with regard to the company-based performance standards. Possibly, the training companies had defined fixed upper performance limits and at the same time established a strong team orientation. This might have given rise to the most talented trainees adjusting their skill acquisition to this level, which was for them suboptimal, in order, at the same time, to meet the demand for team integration.

- The convergence of the performance profiles may in turn also have been a consequence of demotivation of the most gifted. Fixed performance standards only have a motivating and thus challenging effect for the less talented trainees. 


\section{Implications for vocational education and research}

What consequences do these findings imply for training practice, both in companies and in terms of vocational schooling? First of all, it would be wrong to interpret the results presented here as meaning that an identification of gifted trainees is superfluous, because the convergence hypothesis has demonstrated that with increasing vocational training, gifted trainees and average trainees converge with one another and would reach the same performance level in any case. Our results should rather be interpreted as a call for vocational training to support gifted trainees much more strongly than has thus far been the case.

This can be essentially achieved if training companies and vocational schools develop an interest in discovering, recognising, fostering and challenging giftedness potential. On this basis, individual reference norms should be chosen instead of fixed performance standards or even minimal standards, which lie below the trainees' potential. Individual standards have the effect of raising motivation, while fixed standards lead to a levelling out of performance. Consequently, motivation factors should also play a greater role than has so far been the case. Our findings imply at least that a good motivation is indispensible for performance excellence and low motivation slows down the acquisition of knowledge.

It is indisputable that fostering human resources in vocational training is capable of development. If gifted trainees are only able to realise their potential in part, but the top performers convert this extraordinarily well into performance, then a main task for vocational training is formulated: Continue to foster strong performers, but develop talents much more strongly than has previously been the case. Performance excellence is not a static dimension, but rather one that is dynamic and dependent on opportunities for experience and learning, the arrangement of which is an important task for training companies and vocational schools.

For future research with larger samples the question about domain specificity of vocational talent and performance excellence can be considered as a starting point.

\section{References}

Baird, L.L. (1985). Do grades and tests predict adult achievement? Research in Higher Education, 23, 3-85.

Bals, T. (1996). Ausbildungserfolg und Berufsbildungsbiographie. In R. Manstetten (Eds.) Begabtenförderung in der beruflichen Bildung. Empirische und konzeptionelle Beiträge zur Berufsbegabungsforschung. Göttingen: Hogrefe.

Bartenwerfer, H. G. (1978). Identifikation von Hochbegabten. In K. J. Klauer (Eds.) Handbuch der pädagogischen Diagnostik, Band 4. Düsseldorf: Schwann.

Bortz, J. \& Döring, N. (1995).Forschungsmethoden und Evaluation für Sozialwissenschaftler (2nd edition). Berlin/Heidelberg: Springer.

Ceci, S. (1996). General intelligence and life success: an introduction to the special theme. Psychology, Public Policy, and Law, 2, 403-417.

Chi, M.T.H., Glaser, R. \& Farr, M. J. (1988). The nature of expertise. Hillsdale, NJ: Erlbaum.

Eder, F. (1998). Linzer Fragebogen zum Schul- und Klassenklima für die 8.-13. Klasse (LFSK 8-13). Göttingen: Hogrefe. 
Eraut, M. (1994). Developing professional knowledge and competence. London: The Falmer Press.

Ericsson, K. A., Krampe, R. T. \& Tesch-Römer, C. (1993). The role of deliberate practice in the acquisition of expert performance. Psychological Review, 100(3), 363-406.

Fauser, R. \& Egger, S. (2005). Wirkung und Nutzen der Begabtenförderung beruflicher Bildung. Effizienzuntersuchungen. III. Gutachten im Auftrag des Bundesministeriums für Bildung und Forschung. Konstanz: Forschungsstelle für Informationstechnologische Bildung.

Fauser, R. \& Schreiber, N. (1996). Wirkung und Nutzen der Begabtenförderung berufliche Bildung. In R. Manstetten (Eds.) Begabtenförderung in der beruflichen Bildung. Empirische und konzeptionelle Beiträge zur Berufsbegabungsforschung. Göttingen: Hogrefe.

Gagné, F. (1993). Constructs and models pertaining to exceptional human abilities. In K. A. Heller, F.

J. Mönks \& H. A. Passow (Eds.) International handbook of giftedness and talent. Amsterdam: Elsevier.

Gruber, H. \& Ziegler, A. (Eds.). (1996). Expertiseforschung. Theoretische und methodische Grundlagen. Opladen: Westdeutscher Verlag.

Heller, K. A. (Eds.). (2001). Hochbegabung im Kindes- und Jugendalter. Göttingen: Hogrefe.

Horn, W. (1983). Das Leistungsprüfsystem (L-P-S.). Göttingen: Hogrefe.

Hulin, C. L., Henry, R. A. \& Noon, S. L. (1992). Adding a dimension: Time as a factor in the generalizability of predictive relationship. Psychological Bulletin, 107, 328-340.

McDaniel, M.A. (1986). The evaluation of a causal model of job performance. The interrelationship of general mental ability, job experience, and job performance. Unpublished doctoral dissertation, George Washington University.

Nagelkerke, N. J. D. (1991). A note on a general definition of the coefficient of determination. Biometrika, 78, 3, 691-692.

Ostermann, T., Willich, S. N. \& Lüdtke, R. (2008). Regression toward the mean - a detection method for unknown population mean based on Mee and Chua's algorithm. BMC Medical Research Methodology, 8, 52. Retrieved February 2, 2009 from http://www.biomedcentral.com/1471-2288/8/52.

Renzulli, J. S. (1978). What makes giftedness? Reexamining a definition. Phi Delta Kappan, 60, 180-184, 261

Ripper, J. \& Weissschuh, B. (1999). Das ganzheitliche Beurteilungsverfahren für die betriebliche Berufsausbildung. Stuttgart: Christiani.

Sauer, J. \& Gamsjäger, E. (1996). Ist Schulerfolg vorhersagbar? Die Determinanten der Grundschulleistung und ihr prognostischer Wert für den Sekundarschulerfolg. Göttingen: Hogrefe.

Schelten, A. (2002). Begriffe und Konzepte der berufspädagogischen Fachsprache. Stuttgart: Steiner.

Schmidt, F. L., Hunter, J. E., Outerbridge, A. N., \& Goff, S. (1988). Joint relation of experience and ability with job performance: Test of three hypotheses. Journal of Applied Psychology, 73, 46-57.

Schmidt, F. L. \& Hunter, J. E. (1998). Messbare Personenmerkmale: Stabilität, Variabilität und Validität zur Vorhersage künftiger Berufsleistung und berufsbezogenen Lernens. In M. Kleinmann \& B. Strauss (Eds.) Potenzialfeststellung und Personalentwicklung. Göttingen: Verlag für Angewandte Psychologie.

Schneider, W. (1992). Erwerb von Expertise. Zur Relevanz kognitiver und nicht-kognitiver Voraussetzungen. In E. A. Hany \& H. Nickel (Eds.) Begabung und Hochbegabung. Theoretische Konzepte, empirische Befunde, praktische Konsequenzen. Bern: Huber.

Schneider, W. (1999). Expertise. In C. Perleth \& A. Ziegler (Eds.) Pädagogische Psychologie. Grundlagen und Anwendungsfelder. Bern: Huber.

Seiffge-Krenke, I. (1989). Bewältigung alltäglicher Problemsituationen: Ein Coping Fragebogen für Jugendliche. Zeitschrift für Differentielle und Diagnostische Psychologie, 10, 201-220.

Skawran, W. (1965). Ein Test für zwei-dimensionale räumliche Vorstellungen. Diagnostica, 11, 41-45.

Snyderman, M. \& Rothman, S. (1986). Science, politics, and the IQ controversy. The Public Interest, $83,79-97$

Stamm, M. (2007). Kluge Köpfe, goldene Hände. Überdurchschnittlich begabte Lehrlinge in der Berufsbildung. Chur/Zürich: Rüegger.

Stamm, M., Niederhauser, M. \& Müller, R. (2009). Begabung und Leistungsexzellenz in der Berufsbildung. Eine empirische Studie zu den Ausbildungsverläufen besonders befähigter Jugendlicher im Schweizer Berufsbildungssystem. Schlussbericht zuhanden der Berufsbildungsforschung des BBT. Unveröffentlichter Projektabschlussbericht, Universität Fribourg, Schweiz.

Stein, M. (2004). Berufliche Begabung erkennen. Paderborn: Eusl. 
Stein, M., Schmidt, H.-L., Günther, B., Heese, C. \& Babi, B. (2003). Berufliche Begabung erkennen und fördern. Der Modellversuch "Leistungsstarke Auszubildende nachhaltig fördern (LAnf)". Discussion paper in the Schriftenreihe des Bundesinstituts für Berufsbildung, Heft 67.

Sternberg, R. J. (1995). In search of the human mind. Fort Worth, TX: Harcourt Brace College Publishers.

Stiensmeier-Pelster, J., Schürmann, M., Eckert, C. \& Pelster, A. (1994). Der Attributionsstil-Fragebogen für Kinder und Jugendliche (ASF-KJ): Untersuchungen zu seinen psychometrischen Eigenschaften. Diagnostica, 40, 329-343.

Subotnik, R. F., Arnold K. D. (1994). Beyond Terman. Contemporary longitudinal studies of giftedness and talent. Norwood, New Jersey: Ablex Publishing Corporation.

Terman, L.M. \& Oden, M.H. (1959). The gifted child group at midlife. Thirty five years follow-up of the superior child. Genetic studies of genius, Vol. V, Palo Alto: Stanford University Press.

Trautner, H. M. (1992) Lehrbuch der Entwicklungspsychologie. Band 1: Grundlagen und Methoden (2. überarbeitete und ergänzte Aufl.). Göttingen: Hogrefe.

Trost, G. \& Sieglen, J. (1992). Biographische Frühindikatoren herausragender beruflicher Leistungen. In E.A. Hany/H. Nickel (Eds.) Begabung und Hochbegabung. Theoretische Konzepte, empirische Befunde, praktische Konsequenzen. Bern: Huber.

Trudewind, C. (1975). Häusliche Umwelt und Motiventwicklung. Göttingen: Hogrefe.

Wettstein, E. (2000). (Keine) Prognose für die Berufsbildung in zehn Jahren. Forum der Berufsschulen des Kantons Zürich, Nr. 47.

Wigdor, A. K., Garner, W. R. (Eds.). (1982). Ability testing: Uses, consequences, and controversies. Washington D.C.: National Academy Press.

Wild, E. (2003). Einbeziehung des Elternhauses durch Lehrer. Überlegungen und Erkenntnisse zu Art, Ausmass und Bedingung der Elternpartizipation. Zeitschrift für Pädagogik, 513-533.

Ziegler, A. \& Perleth, C. (1995). Begabungs- und Erfahrungsansätze in der Berufspsychologie: Konkurrenz oder Komplementarität? In W. Kusch (Eds). Begabtenförderung in der beruflichen Erst- und Weiterbildung. Neusäß: Kieser.

Ziegler, A. \& Perleth, C. (1997). Schafft es Sisyphos, den Stein den Berg hinaufzurollen? Eine kritische Bestandesaufnahme der Diagnose- und Fördermöglichkeiten von Begabten in der beruflichen Bildung vor dem Hintergrund des Münchner Begabungs-Prozess-Modells. Psychologie in Erziehung und Unterricht, 2, 152-163. 